\title{
ANALYSIS OF THE SECONDARY COMPOUNDS PRODUCED BY SACCHAROMYCES CEREVISIAE AND WILD YEAST STRAINS DURING THE PRODUCTION OF "CACHAÇA"
}

\author{
Maria Cecília Fachine Dato; João Martins Pizauro Júnior; Márcia Justino Rossini Mutton¹ \\ Departamento de Tecnologia, Faculdade de Ciências Agrárias e Veterinárias, Universidade Estadual Paulista, Jaboticabal, \\ SP, Brasil
}

Submitted: April 02, 2004; Returned to authors for corrections: August 20, 2004; Approved: February 10, 2005

\begin{abstract}
The aim of this study is to compare the composition of "cachaças" produced in 10 fermentation cycles by Saccharomyces cerevisiae (Sc) and wild yeast strains [Pichia silvicola (Ps), Pichia anomala 1 (Pa1), Pichia anomala 2 (Pa2) and Dekkera bruxelensis (Db)], isolated from distilleries in Jaboticabal - SP, Brazil. The secondary components of the heart fraction were determined by gas chromatography. The levels of secondary components were influenced by the wine $\mathrm{pH}$, which varied among yeast strains. S. cerevisiae showed slightly more secondary components, whereas wild strains produced more higher alcohols. Wild yeast strains were shown to be adequate for the production of a high quality "cachaça".
\end{abstract}

Key words: "cachaça", distillate composition, aldehyde, higher alcohols, secondary components, yeast

\section{INTRODUCTION}

The sugar cane spirit named "cachaça" is a typical Brazilian drink that is gaining a bigger share in the international market of distilled beverages. The Brazilian production in 2002 season was around 1.3 billion litters. According to the Brazilian Legislation $(4,5)$, sugar cane "cachaça" is a beverage that contains 38 to $48 \%$ (v/v) alcohol and is obtained by distillation of fermented sugar cane juice.

The alcoholic fermentation of sugar cane juice produces ethyl alcohol as its major product and many other secondary components, such as aldehydes, methanol, higher alcohols, acids and esthers. The nature and quality of these components depend on the raw material, fermentation, distillation and ageing. The Brazilian Legislation $(4,5)$ establishes that the secondary components of "cachaça", resulting from the sum of aldehydes, volatile acids, esthers, furfural and higher alcohols, should be

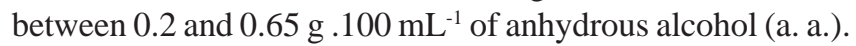

A good balance among volatile compounds is essential to produce a high quality sugar cane spirit or "cachaça" (1). Thus, many studies evaluated the influence of yeast strains in the formation of flavour compounds in different alcoholic beverages such as wine, beer, whisky, cognac and rum $(6,12,13,15,16,25)$. These studies suggest that the differences in the flavour components are attributed mainly to the yeast strains.

Recently, it has been observed that there is a natural substitution of the inoculum cell population by contaminant wild yeasts during the process of fermentation $(3,10,20,23)$. These contaminating yeasts are often shown to be resistant to adverse conditions, such as a high temperature of the medium, substrate and nutrient concentrations, growth rate, and fermentation time, among others. Nevertheless, there is little information about the importance of wild yeasts and their contribution to the quality and aroma of the "cachaça". Besides, it is not yet known if the utilization of non-conventional yeast strains might or not improve the quality of the "cachaça", resulting in a beverage with more stable contents of secondary components. Considering the importance of the wild strains in "cachaça" production, this study determined the main components of the "cachaças" produced by four wild yeast strains, using $S$. cerevisiae as control.

*Corresponding Author. Mailing address: Faculdade de Ciências Agrárias e Veterinárias, UNESP, Laboratório de Tecnologia do Açúcar e do Álcool e Microbiologia das Fermentações, Departamento de Tecnologia, Via de Acesso Prof. Paulo Donato Castellane, s/n. 14884-900, Jaboticabal, SP, Brasil. Telefax: (+5516) 3209-2675. E-mail: mjrmut@fcav.unesp.br 


\section{MATERIALS AND METHODS}

Cotton-filtered sugar cane juice was obtained from a distillery in the region of Jaboticabal, SP, during the season 1999/2000.

The yeasts used in the fermentation process belong to the collection of the Laboratories of Sugar and Alcohol Technology and Fermentation Microbiology - FCAV/UNESP - Brazil. The yeasts were selected based on their unique results in the biochemical tests used for identification and characterization, done as described by Barnett et al. (2) and Kreger van Rij (11). The strains were Pichia silvicola (Ps), Pichia anomala 1 (Pa1), Pichia anomala $2(\mathrm{~Pa} 2)$ and Dekkera bruxelensis $(\mathrm{Db})$. Saccharomyces cerevisiae (Sc) was used as a standard.

The strains were reactivated for $12 \mathrm{~h}$ in $250 \mathrm{~mL}$ of sterile YEPD medium (2\% yeast extract, $1 \%$ peptone and $2 \%$ dextrose), incubated at $30^{\circ}$ and $100 \mathrm{rpm}$. The produced mass was centrifuged and the cells were multiplied in vats (splitting process) using must at $6^{\circ} \mathrm{Brix}$, until enough start was obtained.

The fermentation was performed in two replications using $5 \mathrm{~L}$ of must inoculated with $30 \mathrm{~g}$ cells. $\mathrm{L}^{-1}$. The must was prepared from sugar cane juice at $30^{\circ} \mathrm{C}, 15^{\circ} \mathrm{Brix}$ and $\mathrm{pH} 3.5$. The must was added to the vat hourly during $3 \mathrm{~h}$. The fermentation was carried out in stainless steel vats, using the batch process and 10 fermentation cycles. Each cycle lasted from 17 to $20 \mathrm{~h}$, and the inoculum was decanted and recovered in the end of each cycle. The end of fermentation took place when the substrate indicated $0^{\circ}$ Brix. Cells were then separated and submitted to microbial inoculum treatment ( $\mathrm{pH}$ adjustment to 3.5 and shaking for two hours) and reused in the new fermentation process. Both wine total acidity and $\mathrm{pH}$ were determined as described in Copersucar (9).

The wine was submitted to distillation in a glass apparatus, with a 3-liter carter head with a rectifying column with meandered copper wire. The average distillation time was around 1 hour, which resulted in $2.2 \mathrm{~L}$ of wine. The fractions were separated during distillation considering proportions of $10 \%$ for the head, $80 \%$ for the heart and $10 \%$ for the tail portion. The heart fraction was recovered and individually analysed. The secondary components (acetaldehyde, ethyl acetate, propanol, isobutanol) of the heart fraction were determined by gas chromatography (17).

\section{RESULTS AND DISCUSSION}

The main components of the wine or distillate were ethanol and water, besides a series of volatile substances that distil together and comprise a smaller portion of the wine. These volatiles substances together with the components that are present in higher proportions give peculiar flavour characteristics to the "cachaça". The nature and composition of these components depend on the characteristics of the raw material, and on the fermentation and distillation processes.
According to Soumalainen and Lehtonen (25), the type of inoculum and the fermentation conditions may interfere with the formation of aromatic substances, and may have influence on the production of other substances such as sulphur and phenolic compounds.

During the production of "cachaça", some conditions should be observed in order to obtain a fine quality product, with good aroma and flavour. The spirit should have harmonious proportions of non-alcoholic components, as established by the Brazilian Legislation $(4,5)$.

The content of acetaldehyde, which is the main aldehyde found in "cachaça", ranged from 3.07 to $43.76 \mathrm{mg} .100 \mathrm{~mL}^{-1}$ of anhydrous alcohol (Fig. 1). The legislation allows a maximum value of $30 \mathrm{mg} .100 \mathrm{~mL}^{-1}$ a.a. The highest values were seen in strain Pa1, which were almost 50\% above the legal acetaldehyde limit in the $1^{\text {st }}$ cycle. The strains $\mathrm{Db}$ and $\mathrm{Sc}$ also showed an aldehyde production higher than the permitted values in the $1^{\text {st }}$ and $10^{\text {th }}$ cycles, respectively. Acetaldehyde levels were within the admissible range in the other cycles. Aldehydes are important for aroma and taste of alcoholic beverages (18), but high concentrations may be toxic to humans, since these are considered to be responsible for the disagreeable effects after drinking too much. It is thought that acetaldehyde-rich "cachaças" are originated in distilleries that do not separate the head fraction products during the distillation process (7).

Acetaldehyde production by strains $\mathrm{Pa} 1$ and $\mathrm{Db}$, in the first fermentation cycle; $\mathrm{Pa} 2$ and $\mathrm{Db}$ in the ninth, and $\mathrm{Sc}$ in the tenth, suggest that the levels of acetaldehyde depend on the yeast strain used as inoculum, and also on the conditions in which the fermentation processes and distillation have been carried out. This is supported by the fact that the fractions were separated as recommended in order to obtain a good quality beverage.

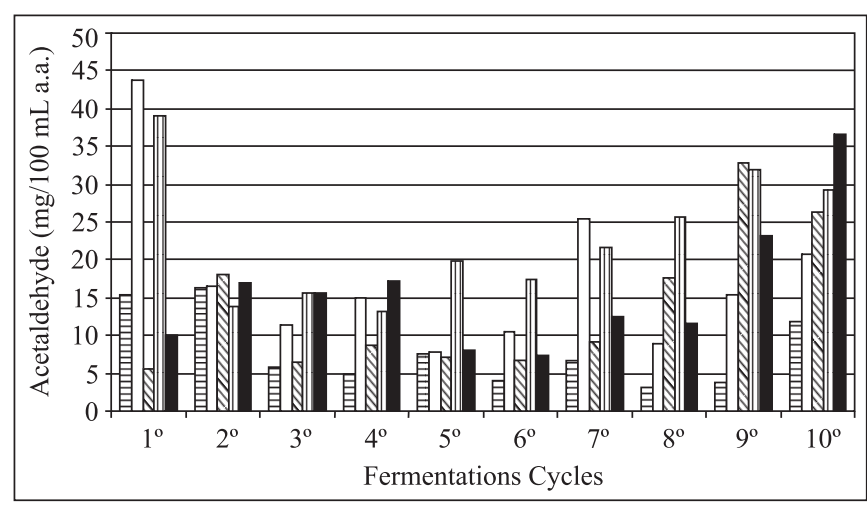

Figure 1. Acetaldehyde levels (mg.100 mL $\mathrm{m}^{-1}$ a.a.) of the "cachaças" produced in 10 fermenting cycles by Pichia silvicola (Ps目), Pichia anomala 1 (Pa1口), Pichia anomala 2 $(\mathrm{Pa} 2 \mathbb{\mathbb { N }})$, Dekkera bruxelensis $(\mathrm{Db} \mathbf{\mathrm { m }})$ and Saccharomyces cerevisiae $(\mathrm{Sc} \square)$, included as a reference. 
The values of ethyl acetate produced by Sc strain in the $3^{\text {rd }}, 4^{\text {th }}$, $9^{\text {th }}$ and $10^{\text {th }}$ cycles (Fig. 2) were above the maximum limit permitted by the legislation, $200 \mathrm{mg} .100 \mathrm{~mL}^{-1}$ anhydrous alcohol. The other strains resulted in values below this limit. Soles et al. (24) have also reported that the highest esther levels were produced by $S$. cerevisiae when compared to other examined yeasts.

Among the wild yeasts producing acceptable ethyl acetate levels, Pa2 produced the highest levels. The mean value of wine acidity was also higher for this strain, followed by the standard strain, (5.01 and $4.78 \mathrm{~g} . \mathrm{H}_{2} \mathrm{SO}_{4} \cdot \mathrm{L}^{-1}$, respectively). The other strains resulted in wine acidity values of $4.37(\mathrm{Db}), 3.39$ (Ps) and 3.33 g. $\mathrm{H}_{2} \mathrm{SO}_{4} \mathrm{~L}^{-1}$ (Pa1). The higher acidity probably contributed to the higher $\mathrm{Sc}$ and $\mathrm{Pa} 2$ production of ethyl acetate in "cachaças" when compared to the other strains. Similar results have been already described and it was concluded that a higher wine acidity was correlated to the higher concentration of ethyl acetate in the distillate that is produced (8).

The concentration of hydrogen ions in the medium correlated inversely with the ethyl acetate concentration present in the final distillate, i.e. the higher the fermentation $\mathrm{pH}$, the lower the ethyl acetate concentration. The mean $\mathrm{pH}$ of the wines produced by $\mathrm{Sc}$ and $\mathrm{Pa} 2$ were 3.24 and 3.31, respectively, while Ps, Pa1 and $\mathrm{Db}$ showed values of 3.40,3.38 and 3.27, respectively.

Methanol may be produced during some steps of "cachaça" production. It is an undesirable component on the final product, due to its high toxicity for humans. No methanol was detected in the samples of the spirits produced by $S$. cerevisiae. Some samples of $P$. silvicola and $P$. anomala 1 showed distillates with minimal quantities of methanol, varying from 0 to $5 \mathrm{mg} .100$ $\mathrm{mL}^{-1}$. These are acceptable levels for "cachaça" because they are not detrimental to the production process and are far below the maximum levels that are permitted (200 mg. $100 \mathrm{~mL}^{-1}$ a.a.).

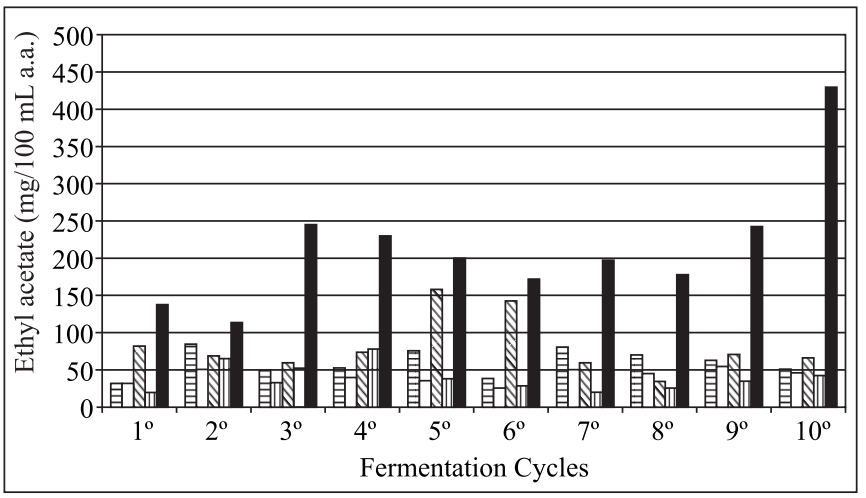

Figure 2. Ethyl acetate levels (mg.100 $\mathrm{mL}^{-1}$ a.a.) of the "cachaças" produced in 10 fermentation cycles by Pichia silvicola (Ps:目), Pichia anomala 1 (Pa1 $\square$ ), Pichia anomala 2 (Pa2\$), Dekkera bruxelensis $(\mathrm{Db} \amalg)$ and Saccharomyces cerevisiae ( $\mathrm{Sc} \square)$, included as a reference.
Methanol production is associated with the acidic degradation of pectine, a polysaccharide that is present in very low quantities in sugar cane bagasse (14). Probably, a great part of the bagasse fragments that came with the must was eliminated, and so was pectin, resulting in a low methanol distillate production.

The analysis of higher alcohols revealed that $\mathrm{Sc}$ produced the lowest propanol levels (Fig. 3) and wild yeasts Pa1 and Ps showed the highest levels. Db and Pa2 also showed higher values than Sc (Figs. 3 to 6). Rankine (21) reported similar results, showing an increase in the quantity of higher alcohols produced by the yeasts when the wine $\mathrm{pH}$ was higher. In the present study, the $\mathrm{pH}$ values of the wines produced by Ps and $\mathrm{Pa} 1$ were 3.4 and 3.38, respectively, whereas $\mathrm{pH}$ was 3.24 for the wine produced by Sc. Propanol concentrations was shown to be proportional to the increase in the $\mathrm{pH}$ of the produced wines.

The highest levels of isobutanol were produced by the strains $\mathrm{Ps}$ and Pa1 in most of the fermentation cycles, followed by $\mathrm{Pa} 2$ and $\mathrm{Db}$ (Fig. 4), while Sc produced the lowest values. As seen for propanol, wine $\mathrm{pH}$ significantly influenced isobutanol levels.

The profile of isoamylic alcohol levels (Fig. 5) was similar to those seen in other higher alcohols. Mean values were the lowest in Sc, whereas Pa1 and Ps showed the highest ones, followed by $\mathrm{Db}$ and $\mathrm{Pa} 2$.

Similar to what was observed for propanol and isobutanol, the $\mathrm{pH}$ of the wine also influenced isoamylic alcohol levels. There was an increase in the $\mathrm{pH}$ of the wine produced in Ps and Pa1 fermentations, which resulted in a higher concentration of isoamylic alcohol, corroborating results from Rankine (21).

The increase in the hydrogen ions of the wine increased the concentration of propylic, isobutylic and isoamylic alcohol in the distillates. According to Soumalainen and Lehtonen (25), the levels of propanol, isobutanol and isoamylic alcohol produced during the fermentation of grape must varied considerably

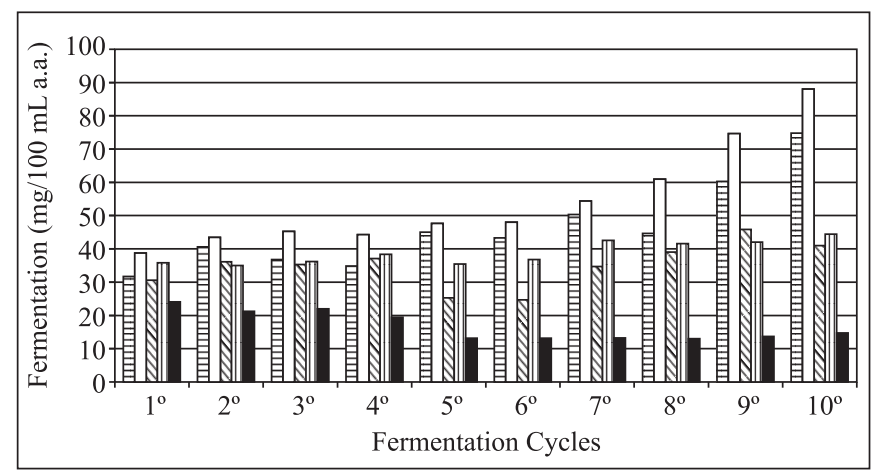

Figure 3. Propanol content (mg.100 $\mathrm{mL}^{-1}$ a.a.) of the "cachaças" produced in 10 fermentation cycles by Pichia silvicola (Ps目), Pichia anomala 1 (Pa1 $\square$ ), Pichia anomala $2(\mathrm{~Pa} 2 \mathbb{\mathbb { Q }})$, Dekkera bruxelensis $(\mathrm{Db} \mathbf{W})$ and Saccharomyces cerevisiae ( $\mathrm{Sc} \boldsymbol{\square})$, included as a reference. 


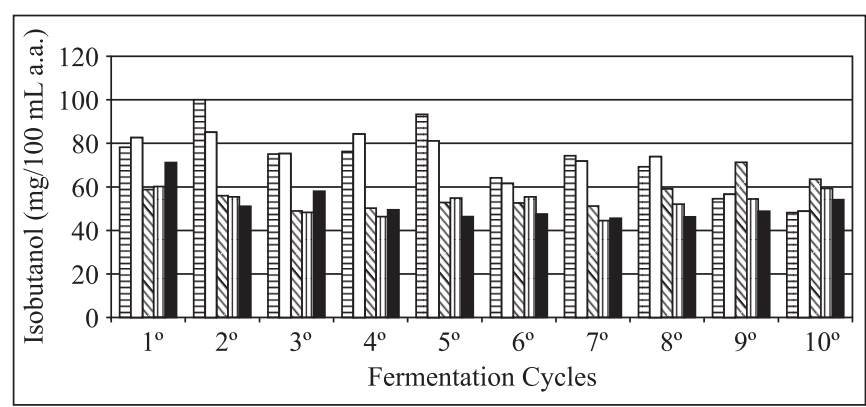

Figure 4. Isobutanol content (mg. $100 \mathrm{~mL}^{-1}$ a.a.) of the "cachaças" produced in 10 fermentation cycles by Pichia silvicola (Ps目), Pichia anomala 1 (Pa1 $\square$ ), Pichia anomala 2 (Pa2田), Dekkera bruxelensis $(\mathrm{Db} \mathbf{W})$ and Saccharomyces cerevisiae ( $\mathrm{Sc} \square)$, included as a reference.

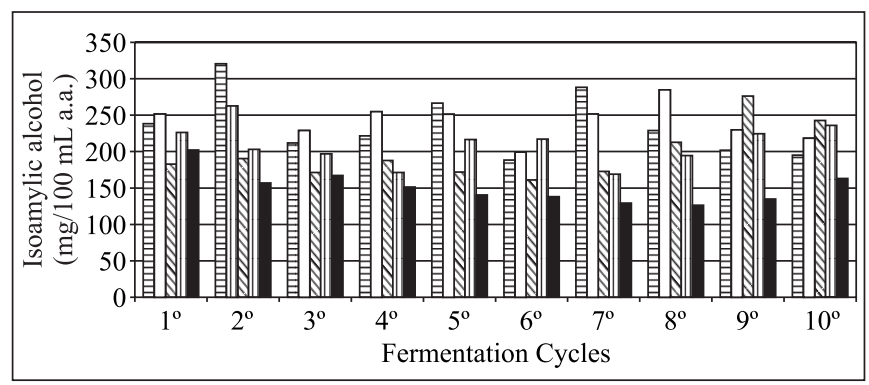

Figure 5. Isoamylic alcohol content (mg.100 mL $\mathrm{mL}^{-1}$ a.a.) of the "cachaças" produced in 10 fermentation cycles by Pichia silvicola (Ps目), Pichia anomala 1 (Pa1 $\square$ ), Pichia anomala 2 (Pa2田), Dekkera bruxelensis (Db四) and Saccharomyces cerevisiae $(\mathrm{Sc} \square)$, included as a reference.

depending on the yeast strain that was used. These results are similar to the obtained in this study, since yeast strains produced different quantities of secondary compounds.

Considering the total of higher alcohols in Fig. 6, the wild strains showed the highest and Sc the lowest levels. Other researchers $(2,12)$ have also reported a lower production of higher alcohols by $S$. cerevisiae, which had the highest levels of ethyl acetate, suggesting that strains that produced more quantities of higher alcohols also had lower esther levels. This profile was also seen for wild strains and Sc in the present study.

The total of secondary components (Fig. 7) ranged from 301.81 to $697.9 \mathrm{mg} .100 \mathrm{~mL}^{-1}$ a.a. The high level of ethyl acetate that was produced by Sc in the $10^{\text {th }}$ cycle resulted in a higher sum of secondary components when compared with the other strains.

The wild yeasts produced acceptable concentrations of all reported compounds. Longo et al. (12) studied the production of higher alcohols, acetaldehyde, ethyl acetate and other components and their findings corroborate the results described in the present study.

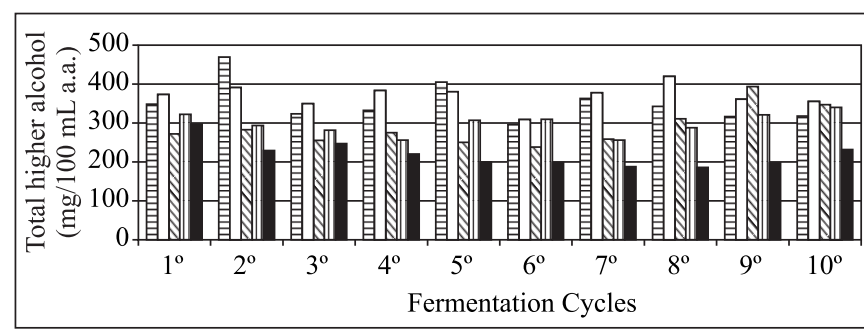

Figure 6. Total of higher alcohols (mg.100 $\mathrm{mL}^{-1}$ a.a.) of the "cachaças" produced in 10 fermentation cycles by Pichia silvicola (Ps目), Pichia anomala 1 (Pa1口), Pichia anomala 2 $(\mathrm{Pa} 2 \mathbb{\mathbb { Q }})$, Dekkera bruxelensis (Db四) and Saccharomyces cerevisiae ( $\mathrm{Sc} \square$ ), included as a reference.

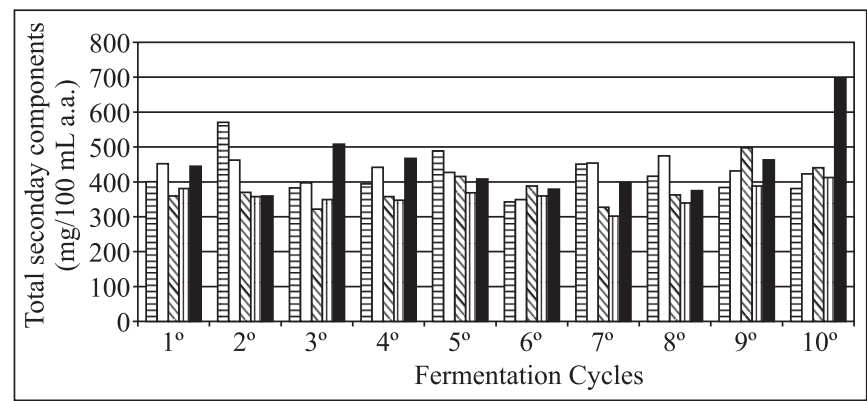

Figure 7. Sum of secondary components (mg. $100 \mathrm{~mL}^{-1}$ a.a.) of the "cachaças" produced in 10 fermentation cycles by Pichia silvicola (Ps目), Pichia anomala 1 (Pa1 $\square$ ), Pichia anomala 2 $(\mathrm{Pa} 2 \mathbb{\mathbb { N }})$, Dekkera bruxelensis $(\mathrm{Db} \mathbf{\mathrm { W }})$ and Saccharomyces cerevisiae ( $\mathrm{Sc} \boldsymbol{\square})$, included as a reference.

The quality and the type of inoculum that is used are very important, since different microorganisms will produce many secondary components in different proportions (22). Thus, inoculum is sometimes considered more important than the raw material used in the fermentation process $(19,22)$.

Since the levels of secondary components were within the range that is permitted by law, the selected wild yeasts ( $P$. silvicola, Ps; P. anomala $1, \mathrm{~Pa} 1 ; P$. anomala $2, \mathrm{~Pa} 2 ; D$. bruxelensis, $\mathrm{Db})$ and $S$. cerevisiae ( $\mathrm{Sc}$ ) may be used to produce "cachaça".

\section{RESUMO}

\section{Análise dos componentes secundários produzidos por Saccharomyces cerevisiae e leveduras selvagens durante a produção de cachaça}

O presente trabalho visou estabelecer uma comparação entre composição de cachaças produzidas por Saccharomyces cerevisiae (Sc) e estirpes de leveduras selvagens [Pichia silvicola (Ps), Pichia anomala 1 (Pa1), Pichia anomala 2 (Pa2) 
e Dekkera bruxelensis (Db)], isoladas em destilarias da região de Jaboticabal-SP. Os componentes secundários da fração denominada coração foram determinados por cromatografia gasosa. Os níveis dos componentes secundários foram influenciados pelo $\mathrm{pH}$ dos respectivos vinhos, os quais dependem da estirpe de levedura empregada no processo fermentativo. A Saccharomyces cerevisiae apresentou valores ligeiramente superiores de componentes secundários, enquanto as estirpes selvagens produziram maiores teores de álcoois superiores. As estirpes selvagens de leveduras mostraram-se adequadas para obtenção de uma cachaça de boa qualidade.

Palavras-chave: cachaça, composição do destilado, aldeídos, álcoois superiores, componentes secundários

\section{REFERENCES}

1. Aquarone, E.; Borzani, W.; Lima, U.A. Biotecnologia. Alimentos e bebidas produzidos por fermentação. São Paulo: Edgar Blucher. 1983. 5, 243p.

2. Barnett, J.A.; Payne, R.W.; Yarrow, D. Yeasts: characteristics and identification. $2^{\text {nd }}$ ed. Cambridge: Cambridge University Press. 1990, $950 \mathrm{p}$.

3. Basso, L.C.; Oliveira, A.J.; Orelli, V.F.D.M.; Campos, A.A.; Gallo, C.R.; Amorim, H.V. Dominância das leveduras contaminantes sobre linhagens industriais avaliadas pela técnica da cariotipagem. STAB, 5, Águas de São Pedro, SP, Anais, 1993. p. 246-250.

4. Brasil. Decreto n.4.072 de 03/01/2002. Dispõe sobre o registro, classificação, padronização, controle, inspeção e fiscalização de bebidas. Diário Oficial. Brasília.

5. Brasil. Portaria Ministerial n. 371, 09/09/1981. Estabelece a complementação dos padrões de identidade e qualidade para os destilados alcoólicos. Diário Oficial, Brasília.

6. Cabrera, M.J.; Moreno, J.; Ortega, J.M.; Medina, M. Formation of ethanol, higher alcohols, esters, and terpenes by five yeast strains in musts fom Pedro Ximénez grapes in various degrees of ripeness. Am. J. Enol. Vitic., 39(4), 283-287, 1988.

7. Chaves, J.B.P.; Póvoa, M.E.B. A qualidade da aguardente de cana-deaçúcar. In: Aguardente de Cana: Produção e Qualidade, Mutton, M.J.R. \& Mutton, M.A. (eds). Jaboticabal, FUNEP, 1992, p. 93132.

8. Cleto, F.V.G.; Mutton, M.J.R. Rendimento e qualidade da aguardente de cana produzida utilizando fermento tratado com ácido sulfúrico e fubá de milho. STAB - Açúcar, Álcool e Subprodutos., 16(2), 38-40, 1997.
9. Copersucar. Manual de controle microbiológico da usina de açúcar e álcool. Cadernos Copersucas - Série Industrial. n.5, Piracicaba - SP, 1983.

10. Guerra, J.B.; Araújo, R.A.C.; Pataro, C.; Franco, G.R.; Moreira, E.S.A.; Mendonça-Hagler, L.C.; Rosa, C.A. Genetic diversity of Saccharomyces cerevisiae during the $24 \mathrm{~h}$ fementative cycles for the production of the artisanal Brazilian cachaça. Lett. Appl. Microbiol., 33, 106-111, 2001.

11. Kreeger - van RIJ, N.J.W. The yeasts - a taxonomy study- $3^{\text {rd }}$ ed. Elsevier Science Publishers B.V. - Amsterdam, 1984. 1082p.

12. Longo, E.; Velazques, J.B.; Sieiro, C.; Cansado, J.; Calo, P.; Villa, T.G. Production of higher alcohols, ethyl acetate, acetaldehyde and other compounds by 14 Saccharomyces cervisiae wine strains isolated from the same region (Salnés, N.W. Spain). World J. Microbiol. Biotech., 8, 539-543, 1992.

13. Lurton, L.; Snakkers, G.; Roulland, C.; Galy, B. Influence of the fermentation yeast strain on the composition of wine spirits. J. Sci. Food Agric., 67, 485-491, 1995.

14. Maia, A.B.R.A. Componentes Secundários da Aguardente. Açúcar, Álcool e Subprodutos, 12(6), 29-33, 1994.

15. Mateo, J.J.; Jiménez, M.; Huerta, T.; Pastor, A. Contribuition of different yeasts isolated from musts of monastrel grapes to the aroma of wine. Int. J. Food Microb., 14, 153-160, 1991.

16. Mateo, J.J.; Jiménez, M.; Huerta, T.; Pastor, A. Comparison of volatiles produced by four Saccharomyces cerevisiae strains isolated from Monastrell musts. Am. J. Enol. Vitic., 43: 208-213, 1992.

17. Monick, J.A. Alcohol - their chemistry, properties and manufacture. New York Reinhold Book. 1986, 576p.

18. Nascimento, R. F. Aldeídos em bebidas alcoólicas fermento-destiladas. Engarrafador Moderno, 49:75-77, 1997.

19. Nykänen, L. Formation and ocurrence of flavour compounds in wine and distilled alcoholic beverages. Am. J. Enol. Vitic., 37:84-96,1986.

20. Pataro, C.; Guerra, J.B.; Petrilho-Peixoto, M.L.; Mendonça-Hagler, L.C.; Linardi, V.R.; Rosa, C.A. Yeast communities and genetic polymorphism of Saccharomyces cerevisiae strains associated with artisanal fermentation in Brazil. J. Appl. Microbiol. London, 89, 24-31, 2000.

21. Rankine, B.C. Formation of higher alcohols by wine yeasts. J. Sci. Food Agric., 18, 583-589, 1967.

22. Reazin, G.; Scales, H.; Andreasen, A. Mechanism of major congener formation in alcoholic grain fermentation. J. Agric. Food Chem., 18(4), 585-589, 1970.

23. Schwan, R.F.; Mendonça, A.T.; Silva Jr.; J.J. da, Rodrigues, V.; Wheals, A.E. Microbiology and physiology of cachaça (aguardente) fermentations. Antonie Van Leeuwenhoek., 79, 89-96, 2001.

24. Soles, R.M.; Ough, C.S.; Kunkee, R.E. Ester concentration differences in wine fermented by various species and strains of yeasts. Am. J. Enol. Vitic., 33, 94-98, 1982.

25. Suomalainen, H.; Lehtonen, M. The production of aroma compounds by yeast. J. Inst. Brew., 85, 149-156, 1979. 